Columbia Law School

Scholarship Archive

1993

\title{
Investment Companies as Guardian Shareholders: The Place of the MSIC in the Corporate Governance Debate
}

Ronald J. Gilson

Columbia Law School, rgilson@law.columbia.edu

Reinier Kraakman

Follow this and additional works at: https://scholarship.law.columbia.edu/faculty_scholarship

Part of the Business Organizations Law Commons

\section{Recommended Citation}

Ronald J. Gilson \& Reinier Kraakman, Investment Companies as Guardian Shareholders: The Place of the MSIC in the Corporate Governance Debate, 45 STAN. L. REV. 985 (1993).

Available at: https://scholarship.law.columbia.edu/faculty_scholarship/893

This Article is brought to you for free and open access by the Faculty Publications at Scholarship Archive. It has been accepted for inclusion in Faculty Scholarship by an authorized administrator of Scholarship Archive. For more information, please contact scholarshiparchive@law.columbia.edu. 


\title{
Investment Companies as Guardian Shareholders: The Place of the MSIC in the Corporate Governance Debate
}

\author{
Ronald J. Gilson* \\ and Reinier Kraakman**
}

Comparative corporate governance is both necessary and hard. Recent scholarship has identified the political and historical contingency of the American pattern of corporate governance. The Berle-Means corporation, ${ }^{1}$ with its separation of management and risk bearing and the attendant agency conflict between managers and shareholders, is now widely recognized as being as much a creature of the American pattern of law and politics as the handiwork of neutral market forces. ${ }^{2}$ This recognition underscores the need to place the American experience in a comparative perspective. Other patterns of corporate governance can provide both insights into the operation of our own and a source of potential reforms; organizational techniques that have worked elsewhere may be transportable. Nevertheless, the very insight that recommends a comparative perspective also indicates the difficulty of the undertaking. It is not only the American pattern of corporate governance that is contingent. A mature comparative scholarship must ultimately explore the political and historical complexity of

\footnotetext{
* Charles J. Meyers Professor of Law and Business, Stanford University, and Professor of Law, Columbia University.

** Professor of Law, Harvard University. This article draws on an earlier report commissioned by Jan Stenbeck, a director and shareholder of Industriförvaltnings AB Kinnevik. Gilson's research was supported by the Kendyl K. Monroe Research Fund and the John M. Olin Program in Law and Economics, at Stanford Law School. Kraakman's research was supported by the Harvard Law School Faculty Summer Research Program and the Harvard Program on Law and Economics, which is funded by the John M. Olin Foundation. We are grateful to Bernard Black, Victor Brudney, Mathew Chambers, John C. Coffee, Jr., Jeffrey Gordon, R.J. Gormley, Howell Jackson, Mark J. Roe, Roberta Romano, and participants at the Conference on Institutional Investors and Corporate Governance, University of Osnabrück, July 9-11, 1992, for helpful comments on an earlier draft of this article.

1. So named for the pioneering treatment of the separation of ownership and control in the American public corporation by Adolph Berle and Gardiner Means. See AdolPH A. BERLE, JR. \& Gardiner C. Means, The Modern Corporation and Private Property (1932).

2. See, e.g., Bernard S. Black, Shareholder Passivity Reexamined, 89 MicH. L. Rev. 520 (1990); John C. Coffee, Jr., Liquidity Versus Control: The Institutional Investor as Corporate Monitor, 91 Colum. L. REv. 1277 (1991); Joseph A. Grundfest, Subordination of American Capital, 27 J. Fin. ECON. 89 (1990); Michael C. Jensen, Eclipse of the Public Corporation, HARV. Bus. REv., Sept.-Oct. 1989, at 61; Mark J. Roe, A Political Theory of American Corporate Finance, 91 ColuM. L. REV. 10 (1991).
} 
every major corporate governance structure. ${ }^{3}$ Even before this enterprise is complete, however, comparative analysis can still carry important policy implications for those of us who have the more limited agenda of making incremental improvements in our own governance structures. Foreign techniques can be evaluated in terms of their potential contributions to one's own system, even without a complete understanding of their origins and function in their domestic contexts.

In this article, we undertake such a limited exercise in comparative corporate governance as part of a continuing project to devise incremental improvements in the American pattern of corporate governance. Our focus here is a little noted European, and particularly Swedish, form of financial intermediary, which we call a Managerial Strategic Investment Company (an "MSIC"), that may be peculiarly suitable for American transplant. The MSIC's special characteristic is that, consistent with non-U.S. corporate governance systems, it is an intermediary that serves as an active monitor of the performance of its portfolio companies. Consistent with the American corporate governance system, however, its only tie to its portfolio companies is its equity investment. Unlike the German and Japanese systems, the link between the financial intermediary and its portfolio companies is onedimensional.

Our strategy is intentionally modest: We propose an incremental reform of American corporate governance that can be implemented within the broad confines of the existing system. For those who have concluded that the entire system is fundamentally flawed, so limited a strategy may seem pointless and, indeed, pernicious. ${ }^{4}$ From our perspective, the limits on our strategy simply reflect the reality of path dependency. More ambitious reform may be desirable, but only if it is attainable - a judgment that requires a far deeper understanding of the contingencies of different governance systems than we now possess. In the meantime, the measure of our efforts is whether they can improve the system we have, not whether a deeper restructuring of our pattern of governance would be even better. ${ }^{5}$

Part I sketches three different patterns of monitoring structures that can be observed in existing corporate governance systems. This highlights the special characteristic of the American pattern into which the MSIC must fit

3. Mark J. Roe, Some Differences in Corporate Structure in Germany, Japan, and America, 102 YALE L.J. (forthcoming June 1993) (manuscript on file with the Stanford Law Review) is an ambitious effort in this direction.

4. For example, Michael Porter, of the Harvard Business School Project on the Time Horizons of American Management, has urged that not only must the entire American corporate governance system be reformed, including restructuring the American financial system, but that the entire project must be accomplished simultaneously. Michael Porter, Remarks at the Securities and Exchange Commission Public Forum on Corporate Governance and American Competitiveness: The Role of Shareholders, Directors and Management 53-54 (Mar. 19-20, 1992) (transcript on file with the Stanford Law Review).

5. We are reminded of the retort of the man who, on seeing a charging grizzly bear, stopped to put on running shoes. When his companion rebuked him, pointing out that the grizzly bear could not be outrun, he responded that he did not have to outrun the grizzly bear; he only had to outrun his companion. 
in order to be suitable for transplant-a pattern in which the role of monitoring management is assigned primarily to those entities whose sole function is to supply the corporation with equity capital. In Part II, we introduce the MSIC as part of our ongoing project of incremental reform; we describe the structure of the MSIC and explain its fit within the American pattern of monitoring. Part III considers the regulatory barriers to implementing an MSIC strategy in the United States. Finally, Part IV evaluates the likelihood of success of an American MSIC strategy from three perspectives: the potential for a conflict of interest between the MSIC and other shareholders of portfolio companies, the relevance of the closed end mutual fund paradox to MSICs, and the available empirical evidence on the influence of large shareholders on firm performance.

\section{Patterns of Monitoring}

Any system in which separately owned factors of production cooperate to produce a good or service must have a mechanism that, more or less successfully, monitors the participants' diligence and quality of performance. The leading corporate governance systems reflect three quite different patterns of monitoring: bank-centered monitoring, exchange-centered monitoring, and investor-centered monitoring. While no existing system presents a pure type of any of the patterns, the corporate governance systems of Germany, Japan, and the United States each reflect a characteristic orientation. For our purposes, that characteristic orientation sets the path-dependent limits for our strategy of incremental reform. A brief review of the patterns of monitoring in Germany and Japan will highlight the limitations imposed by the American pattern into which an MSIC strategy must fit to serve our goal of incremental reform within the system's overall paradigm. In the American system, monitoring is limited to investors whose relation to the corporation is one-dimensional: They provide only equity capital.

\section{A. German Bank-Centered Monitoring}

The German system has been characterized as bank-centered monitoring. Representatives of major banks sit on the supervisory boards of the leading German industrial corporations. ${ }^{6}$ In that capacity, bank representatives are truly independent of management because they serve at the instance of the banks, not management. The influence of the banks appears to result from their multidimensional relationship with German industry. German banks have historically been a major source of debt capital for German industry, ${ }^{7}$ and the primacy of debt capital leverages not only the borrower's

6. See Theodor Baums, Corporate Governance in Germany: The Role of the Banks (Stanford University, Center for Economic Policy Research Publications No. 311, Aug. 1992) (reporting the extent of bank representation on the boards of directors of the 100 largest German firms). Bank managers of the nine largest banks had one or more seats on the supervisory boards of 96 of the largest 100 firms, and a bank representative was president of 14 such firms.

7. See Alfred D. Chandler, JR., SCale ANd Scope: The Dynamics of Industrial CapITALISM 415-19 (1990). 
capital structure, but the lender's influence as well. But provision of credit is not the only lever of power held by the banks. In forty-two of the 100 largest German companies, three banks control an average of 45 percent of each company's voting stock. ${ }^{8}$ This concentration of voting control comes from three sources: the banks' direct stock holdings, the holdings of mutual funds operated by the banks, and the proxy votes of bearer shares deposited with banks through the banks' stock brokerage operations. ${ }^{9}$

Taken together, the universal bank sits at the epicenter of German corporate governance. The combined roles of lender, record and beneficial stockholder, and director put the bank representative in a unique monitoring position. It has the position, information, and power to effectively monitor the activity of management and, when necessary, to discipline management. ${ }^{10}$

\section{B. Japanese Exchange-Centered Monitoring}

The Japanese corporate governance system, while sharing with the German system an important role for large banks, ${ }^{11}$ differs markedly in its pattern of monitoring, because an important element of the system is its focus on supporting efficient, productive exchange between affiliated companies, rather than the agency problem itself. ${ }^{12}$ The keiretsu, especially in its verti-

8. Roe, supra note 3, at app., tbl. I. Expanding the analysis to include five banks raises the average to above $50 \%$ of each company's voting stock. Id.

9. Id. at 10; see also TheOdOR BAUMS, BANKS AND CoRporate ConTrol (University of California at Berkeley, Program in Law and Economics Working Paper No. 91-1, July 1991). While many German companies have adopted bylaw provisions that cap the voting power of any single shareholder at $5 \%$, these limits do not apply to banks in their capacity as proxy holders; apparently the calculation is based on beneficial ownership. Baums, supra note 6 , at 6 .

For an account of the German system of depository voting, see Johannes Köndgen, Duties of Banks in Voting Their Clients' Stock (paper presented at the Conference on Institutional Investors and Corporate Governance, University of Osnabrück, July 9-11, 1992) (on file with the Stanford Law Review).

10. How energetically the banks actually exercise the power inherent in their unique position remains uncertain. See, e.g., Baums, supra note 6, at 6 . However, the banks' absolute power to elect nonemployee representatives to the supervisory board through control of a majority of the voting stock, and the exercise of that control through the placement of bank representatives on supervisory boards, creates the potential for effective control whether or not it is actually exercised. Id. Of course, the more effective the exercise of power, the more difficult it may be to observe. However, at least the banks' proxy voting power depends on the terms of German corporate legislation. If German corporations can make a credible claim that the banks' exercise of voting power would be met by corporate sponsored efforts to amend the relevant corporate legislation, the absence of observable exercise of power by the banks may have a different interpretation. In this regard, Professor Kübler reports that in recent years German banks have taken the public position that they wish to relinquish their role as proxy holders. See Friedrich Kübler, Institutional Ownership and Corporate Governance: A German Perspective 13 n.53 (paper presented at the Conference on Institutional Investors and Corporate Governance, University of Osnabrück, July 9-11, 1992) (on file with the Stanford Law Review).

11. See, e.g., Masahiko Aoki, Toward an Economic Model of the Japanese Firm, 28 J. EcoN. LrTerature 1, 14-16 (1990); Paul Sheard, The Main Bank System and Corporate Monitoring and Control in Japan, 11 J. Econ. Behav. \& Organization 399, $401-03$ (1989); Paul Sheard, Delegated Monitoring Among Delegated Monitors: Principal-Agent Aspects of the Japanese Main Bank System 2-3 (Apr. 1991) (unpublished manuscript, on file with the Stanford Law Review).

12. See Ronald J. Gilson \& Mark J. Roe, Understanding the Japanese Keiretsu: Overlaps Between Corporate Governance and Industrial Organization, 102 YALE L.J. 871, 881-82 (1993). 
cal form, is composed of a group of firms which typically share two relationships: cross-exchanges and cross-shareholdings. Member firms hold equity positions in other group members and supply each other with factors of production. ${ }^{13}$ A keiretsu's main bank may be first in both the size of its crossshareholdings and the importance of the factor of production it provides, but for our purposes, the critical characteristic is the multidimensional monitoring pattern. While the main bank may once have monitored projects in its role as major lender, ${ }^{14}$ and still leads rescue operations in the event of crisis, ${ }^{15}$ real-time day-to-day monitoring of performance occurs through the substantive exchange relationship between nonfinancial members of the keiretsu. For example, a just-in-time inventory system provides not just parts, but current information about the quality of a supplier's performance. ${ }^{16}$ Thus, the Japanese monitoring pattern, like the German pattern in this critical respect, reflects a multidimensional relationship between the company and its monitors.

\section{American Investor-Centered Monitoring}

For reasons explored most thoroughly by Mark Roe, the American corporate governance system has sharply constrained the development of multidimensional governance relationships. ${ }^{17}$ By restricting the size of banks and the scope and geographical range of their activities, the regulatory web enveloping the American financial services industry has tightly restricted bank influence. Neither their credit provision function nor their limited equity ownership ${ }^{18}$ provide banks with sufficient power and incentive to monitor.

13. The extent of these features depends on whether a keiretsu is primarily horizontal or vertical. A horizontal keiretsu comprises firms which span a wide range of industries, while a vertical relationship is industry-specific. For helpful descriptions of the keiretsu structure, see MiCHAEL L. Gerlach, Alliance Capitalism: The Social Organization of Japanese Business 4-6 (1992); Ulrike Schaede, Corporate Governance in Japan: Institutional Investors, Management Monitoring and Corporate Stakeholders 11-20 (paper presented at the Conference on Institutional Investors and Corporate Governance, University of Osnabrück, July 9-11, 1992) (on file with the Stanford Law Review).

14. See W. Carl Kester, Japanese Takeovers: The Global Contest for Corporate CONTRol 195-97 (1991) (observing that successful Japanese firms are now free from main bank review of strategy and capital budgeting); Paul Sheard, Japanese Corporate Finance and Behaviour: Recent Developments and the Impact of Deregulation, in JAPANESE FINANCIAL MARKETS AND THE ROLE OF THE YEN 55, 56 (Colin McKenzie \& Michael Stutchbury eds., 1992) (noting that from the early $1970 \mathrm{~s}$ to mid-1980s, the percentage of the net increase in corporate funds from bank borrowings dropped from $41 \%$ to $6 \%$ ).

15. See Aoki, supra note 11, at 15-16; Takeo Hoshi, Anil Kashyap \& David Scharfstein, The Role of Banks in Reducing the Costs of Financial Distress in Japan, 27 J. FIN. EcoN. 67, 73-74 (1990).

16. See Aoki, supra note 11, at 5. Likewise, cross-shareholdings prevent opportunism and thereby support investment by keiretsu members in relation-specific assets. The investment provides both a monitoring relationship and supplies the necessary incentive to monitor. Joint investment in relation-specific assets in the face of a competitive market means that the value of one party's investment is hostage to the performance of the other. Thus, the means and the motive for day-to-day monitoring are provided simultaneously. Gilson \& Roe, supra note 12, at 892.

17. See Roe, supra note 2, at 10; Roe, supra note 3, at 1-9.

18. Bank holding companies are prohibited from holding more than $5 \%$ of a portfolio com- 
As a result, the monitoring role in the American corporate governance system is relegated to those who provide only equity capital to the corporation-the shareholders. This characteristic has forced American governance institutions to follow a unique Berle-Means pattern of successive efforts, ranging from independent directors to hostile takeovers, to bridge the separation of ownership and management in the face of dispersed shareholdings. The formal governance structure of the Berle-Means corporation, under which a board of directors elected by shareholders monitors management, has been less than effective. To be sure, almost three-quarters of the directors of publicly-held companies in the United States are independent in the formal sense that they are not full-time company employees. ${ }^{19}$ Nevertheless, because outside directors are typically chosen by management, ${ }^{20}$ and because 63 percent of outside directors are chief executives of other publiclyheld companies, ${ }^{21}$ such directors have traditionally had little commitment to or enthusiasm for active monitoring. Hostile takeovers have been a peculiarly Anglo-American phenomenon, reflecting in part the absence of effective monitoring mechanisms whose operation would be triggered short of the dramatic value gap necessary to make a control fight economically viable. ${ }^{22}$

Thus, the American corporate governance pattern has restricted the monitoring function to investors, but the dispersal of shareholdings has prevented investors from making serious efforts to discharge the monitoring function. This structure sets the framework for efforts at incremental reform of American capital governance: How can investors whose only link to the corporation is the provision of equity capital develop the capacity to monitor management effectively?

\section{INCREMENTAL GOVERNANCE REFORM AND THE MSIC}

The one-dimensional character of corporate governance in the United States goes far toward reducing corporate monitoring to a simple agency problem between shareholders and managers. Such simplicity makes governance particularly transparent in the American context. Unfortunately, it also greatly limits the range of incremental reforms that might improve corporate monitoring within the confines of the larger governance system. On one hand, only shareholders can monitor management. On the other hand, shareholders, when small and dispersed, lack the incentive to become effective monitors unless the costs of collective action can be reduced to make

pany, and, as interpreted by regulators, the $5 \%$ holding must be passive. See Roe, supra note 3 , at 19.

19. Jay W. Lorsch \& Elizabeth Maciver, Pawns or Potentates: The Reality of AMERICA'S CORPORATE BOARDS 17 (1989).

20. "[O]ur data reveal that ... many directors still feel they are serving at the pleasure of the CEO-chairman." Id.

21. Id. at 18.

22. Michael Porter states the issue straightforwardly: "Investors exercise little real influence on managements, and are rarely represented on boards of directors. The only mechanism left to discipline poorly performing managements is takeovers or mergers . ..." MICHAEL E. PORTER, The COMPETITIVe AdVANTAGe of Nations 529 (1990). 
coordinated monitoring feasible. It follows that any practical reform proposal must address the costs of collective action, the size of shareholdings, or both. ${ }^{23}$

Our initial reform proposal built upon an already existing opportunity to improve monitoring. ${ }^{24}$ Due to recent increases in the scale of institutional shareholdings, the costs of collective action among institutional shareholders have significantly decreased. ${ }^{25}$ In our earlier proposal, we urged institutional investors, and particularly public pension funds, to resurrect the corporate board as a monitoring structure by supporting a new class of professional independent directors. The key feature of professional directors would not merely be their independence from management but, more importantly, their dependence on shareholders and, in particular, on institutional shareholders for their continued tenure as directors. In short, we proposed to reward good monitors with very good jobs on the condition that they remain good monitors on behalf of shareholder interests. ${ }^{26}$

In this article, we offer a second reform proposal-the MSIC as a guardian shareholder-that complements our proposal for professional directors. Where the professional director strategy provided a blueprint for cooperation among large but individually powerless shareholders, the MSIC strategy would internalize such cooperation through a new entity that would itself acquire sufficient shareholdings to support effective monitoring. The MSIC strategy is the more novel reform proposal, insofar as it would open the American market to a new investment form. In another sense, however, the MSIC strategy is the more conservative reform. A new investment vehicle takes time to develop, and because it is likely to start small, it is also likely to have its initial effect on smaller corporations. Moreover, because the MSIC strategy does not implicate the regulatory restrictions on coordinated activ-

23. See Black, supra note 2, at 525 .

24. Ronald J. Gilson \& Reinier Kraakman, Reinventing the Outside Director: An Agenda for Institutional Investors, 43 STAN. L. REv. 863, $883-92$ (1991); see also Ronald J. Gilson, Lilli A. Gordon \& John Pound, How the Proxy Rules Discourage Constructive Engagement: Regulatory Barriers to Electing a Minority of Directors, 17 J. CoRP. L. 29, 45-47 (1991) (proposing proxy rule reform to facilitate election of minority director slates by institutional investors, adopted by the SEC in its recent package of proxy rule revisions).

25. Institutional investors now purportedly own more than half of the stock of the largest American corporations. Carolyn Kay Brancato, The Pivotal Role of Institutional Investors in Capital Markets, in INSTITUTIONAI INVESTING: ChALLENGES AND RESPONSIBILITIES OF THE 21sT CENTURY 3, at 21, tbl. 1-7 (Amold W. Sametz \& James L. Bicksler eds., 1991).

26. Our goal was to design a position that would be desirable to individuals with the skills to be effective monitors. The desire to retain an attractive position would create a performance incentive that outside directors currently lack. In other words, we hoped to create a real market for outside directors. We suggested a full-time position obligating each expert to serve on the boards of perhaps six corporations. Total compensation from board fees and benefits easily might exceed $\$ 250,000$. Individuals with the required talents "could undoubtedly earn more in other employment, but they would be hard-pressed to match the intrinsic interest of the professional director's work or the social prestige that multiple directorships would confer." Gilson \& Kraakman, supra note 24, at 885. Such directors would then have the two essential resources for effective monitoring that traditional outside directors lack: a focused mandate, provided by the desire to retain a position truly filled by shareholders; and sufficient time to spend on a company's affairs, provided by the full-time character of the position. 
ity among existing investors or call upon public pension funds to take a leading role in reform, it is immune to the legal and political objections that some critics have made to our proposal for professional directors. ${ }^{27}$

\section{A. The Structure of the MSIC}

We define an MSIC as a publicly-traded financial intermediary-a closed-end investment company-that pursues a core strategy of making large and active equity investments in a small portfolio of public companies. As such, the MSIC form is virtually unknown in the United States. ${ }^{28}$ Yet, it seems commonplace in Europe, where many of the largest corporate "groups" can be classified as MSICs. ${ }^{29}$ The MSIC form is particularly prominent in Sweden, where its role in corporate governance has received widespread recognition.

Like financial investors in the United States, most Swedish financial investors are legally disabled from intervening in the affairs of public corporations. Swedish banks lack significant share holdings, and Swedish law limits the stakes of insurance companies, mutual funds, employee stock ownership funds, and pension funds to less than 5 percent of the voting stock of individual companies. ${ }^{30}$ Unlike the United States, however, Sweden permits closedend investment companies to function as true MSICs, which are not only allowed to invest actively in public corporations, but are encouraged to do so. ${ }^{31}$ As a result, publicly-held MSICs are presently the second largest insti-

27. See Black, supra note 2, at 530; Coffee, supra note 2, at 1359-62; Martin Lipton \& Steven A. Rosenblum, $A$ New System of Corporate Governance: The Quinquennial Election of Directors, 58 U. CHI. L. REv. 187, 206 (1991); Edward B. Rock, The Logic and (Uncertain) Significance of Institutional Shareholder Activism, 79 GEO. L.J. 445, 474-75 (1991).

28. In Part III, we show that the Investment Company Act of 1940 effectively prohibits American MSICs. Warren Buffett's investment vehicle, Berkshire Hathaway, Inc., is the closest approximation to an MSIC in the United States. See text accompanying note 79 infra.

29. Established European MSICs include VIAG AG in Germany; Societe Generale de Belgique (Generale) in Belgium; Groupe Suez and Pechelbronn in France; and Ferruzzi Finanziaria, Compagnie Industriali Riunite (CIR), Instituto Finanziario Industriale (IFD) in Italy. We describe two prominent Swedish MSICs, Industrivärden and Kinnevik, in greater detail at note 34 infra and accompanying text. Each of these MSICs maintains a portfolio of large operating companies in which it is a controlling shareholder, a portfolio of public corporations in which it is a "strategic partner" or large-block investor, and a much larger number of investments in small or start-up private firms. The MSICs differ in the relative sizes of their controlling shareholder, large-block shareholder, and private portfolios. The English editions of their most recent annual reports include detailed accounts of their holdings. For a discussion of the Belgian version of the MSIC, see Eddy Wymeersch, Institutional Investors and Financial Groups in Belgium (paper presented at the Conference on Institutional Investors and Corporate Governance, University of Osnabrück, July 9-11, 1992) (on file with the Stanford Law Review).

30. Rolf Skog \& Mats Isaksson, Ownership and Control in the Swedish Business Sector 8-9 (paper presented at the Conference on Institutional Investors and Corporate Governance, University of Osnabrück, July 9-11, 1992) (on file with the Stanford Law Review). Skog and Isaksson provide an English summary of the report of the Swedish Parliamentary Commission on Stock Ownership and Efficiency, which was submitted to the Swedish Parliament in 1988. For further discussion of the Swedish Parliamentary Commission's report, see Coffee, supra note 2, at 1306-08.

31. Thus, the Swedish Parliamentary Commission on Stock Ownership and Efficiency "considers it important that investment companies are able to continue to exercise this [active ownership] function and find [sic] it worthwhile considering whether the tax situation of investment companies 
tutional holders of equities. ${ }^{32}$ Moreover, their prominent position in the Swedish market has led to public recognition of their capacity to monitor the performance of Sweden's public corporations. ${ }^{33}$

To see how Swedish MSICs have earned such recognition, consider two large Swedish MSICs: AB Industrivärden and Industriförvaltnings AB Kinnevik. Like the typical American closed-end investment fund, one of these Swedish MSICs (Kinnevik) devotes a portion of its capital to a diversified portfolio of publicly-traded securities; and like an American venture capital fund, both MSICs are controlling parents of several closely-held start-up companies. However, their central investment strategy-taking strategic minority positions in a handful of publicly-traded operating companieslacks an American counterpart. These positions, which range from 3 to 49 percent of the voting equity of the companies in their strategic portfolios, are large enough to assure board representation, but too small to provide outright voting control. ${ }^{34}$

The Swedish MSICs are also long-term investors in their strategic portfolio companies. Large holdings are rarely sold except as a result of a merger or similar restructuring of an affiliated operating company. ${ }^{35}$ In addition, as significant minority investors, the Swedish MSICs play an active role in the management of their affiliated companies. Like American leveraged buyout syndicates and venture capital firms, ${ }^{36}$ they maintain a staff of senior manag-

ought to be changed" to encourage further large-block holdings. Skog \& Isaksson, supra note 30 , at 26.

32. As of January 1992, Swedish MSICs held $10 \%$ of the total market capitalization of the Stockholm Stock Exchange, insurance companies (which also manage pension assets) held 15\%, and mutual funds held 9\%. Mats Isaksson \& Rolf Skog, Corporate Governance in Swedish Listed Companies 4 (Nov. 1992) (unpublished manuscript, on file with the Stanford Law Review). Proportionate MSIC holdings were higher in 1985, when, after a decade of growth, they reached $16 \%$ of total market capitalization and constituted the largest class of Swedish institutional equity holdings. Skog \& Isaksson, supra note 30, at 12, tbl. 1. The decline in the relative size of MSIC holdings since 1985 resulted in part from changes in Swedish tax law that favored mutual funds and private pension insurance policies, and in part from a persistent closed-end fund discount that dogged Swedish MSICs in the 1980s. Id. at 5-6 (regarding Swedish tax law changes); see text accompanying notes 84-89 infra (discussing closed-end fund discounts). Yet, the magnitude of the decline in Swedish MSIC holdings is probably overstated in a comparison of the 1985 and 1992 data. The 1992 data, but not the 1985 data, include Swedish equities held by nonfinancial companies (20\% of total equities). Since these nonfinancial companies are themselves held largely by financial investors, breaking out nonfinancial equity holdings dilutes the proportionate holdings of financial investors, including MSICs, in the 1992 data.

33. Skog \& Isaksson, supra note 30 , at $26,29-30$.

34. See AB INDUSTRIVÄRDEN, NinE-MONTH REPORT: JANUARY 1-SEPTEMBER 30, 1990, at 14-15 (1990) (holdings from $3 \%$ to $26 \%$ of voting equity in 10 public companies); INDUsTRIFÖRVALTNINGS AB KINNEVIK, 1989 ANNUAL REPORT 31 (1990) [hereinafter KINNEVIK] (holdings from $10 \%$ to $49 \%$ of voting equity in five public companies). In this regard, MSICs differ from their Belgian counterparts, which are more likely to hold an absolute majority of the stock in their portfolio companies. See Wymeersch, supra note 29, at 10-16.

35. See, e.g., Letter from Jan Stenbeck to Jonathan G. Katz, Secretary, Securities and Exchange Commission 2 (Oct. 10, 1990) (on file with the Stanford Law Review) (detailing Kinnevik's policy of stable holdings).

36. For a discussion of the operation of leveraged buyout firms, see Jensen, supra note 2, at 61 . The relationship of venture capital funds to their portfolio companies is described in William A. Sahlman, The Structure and Governance of Venture-Capital Organizations, 27 J. FiN. EcoN. 473 (1990). 
ers with operating expertise to advise the managements of their affiliated companies and, when necessary, to press for changes in the management of unsuccessful companies. ${ }^{37}$

However, these MSICs differ from leveraged buyout syndicates in two important respects. First, MSICs are themselves publicly-held companies, meaning they are not restricted to raising capital through bonds and bank loans; they can also issue new stock. Second, MSICs ordinarily assume a minority, rather than controlling, position in other public firms-an investment rather than a takeover. As a result, MSICs establish a symbiotic relationship with smaller public shareholders in their operating companies. Because such operating companies still have public shareholders, the MSICs enjoy the benefit of a market price by which to measure the performance of their publicly-held assets. ${ }^{38}$ In turn, smaller investors in a company held in an MSIC portfolio obtain the services of a guardian shareholder-an independent monitor on the board who actively safeguards the interests of all shareholders. Anecdotal evidence indicates that public investors in an MSIC's operating affiliates closely follow the MSIC's investment decisions and policy recommendations. ${ }^{39}$

\section{B. The Fit of MSICs in the American Governance System}

In Sweden, as well as elsewhere in Europe, MSICs are specialized governance responses to particular regulatory and political environments. Nevertheless, precisely because these MSICs mediate between dispersed shareholders and the managements of public corporations, and because their relationship with their portfolio companies is one-dimensional-the only tie is through their equity investments-they are consistent with the American pattern of corporate governance. Moreover, it appears that MSICs perform a monitoring function in their national markets that no existing American institution fully serves in our own market. Direct control of operating companies by America's existing financial investors-pension funds, banks, and insurance companies-is simply not in the cards. A dramatic revival of the takeover market, even if possible, would be a costly substitute for effective internal governance. And a meaningful reform of the existing system of outside directors, which we believe is both desirable and feasible, has yet to command the attention of institutional investors whose cooperative action

37. See Letter from Jan Stenbeck to Jonathan G. Katz, supra note 35, at 2-3.

38. Katherine Schipper \& Abbie Smith, A Comparison of Equity Carve-Outs and Seasoned Equity Offerings: Share Price Effects and Corporate Restructuring, 15 J. FIN. EcoN. 153 (1986) (offering empirical evidence on the value of market performance measurement).

39. Further evidence of the quality of the active investment services provided by Swedish MSICs lies in the fact that MSIC shareholders are often savvy investors themselves, in contrast with the United States, where institutional investors seldom invest in closed-end investment companies. For example, two-thirds of Industrivärden's stock is held by 10 institutions, including major insurance companies and pension funds. AB INDUSTRIVÄRDEN, supra note 34, at 11 . The remaining shares are held by about 15,000 investors. Id. It thus appears that the Swedish MSICs are market devices for collectivizing the monitoring costs of all public investors, large and small. 
would be necessary to implement it. ${ }^{40}$ Against this backdrop, a proposal to allow American MSICs to take long-term stakes in public companies could make an important contribution to governance reform as well as to the welfare of individual investors.

Following the European MSIC model, American MSICs would invest in small numbers of companies selected for their potential value and their compatibility with the business expertise of the MSIC managers. A range of MSIC strategies might be possible. For example, some MSICs might specialize in the rehabilitation of distressed or poorly performing companies, while others might target rapidly growing firms needing equity capital. Whatever an MSIC's strategic focus, however, MSIC investments would generally be friendly transactions, if only because the MSIC strategy turns on obtaining effective board representation without waging a costly control contest. Although some corporate managements might turn down an MSIC's offer of capital for board representation, others would accept it for the same reasons that many American companies now welcome large private investors. MSICs could not threaten to displace management or alter corporate policy without the support of non-MSIC directors and investors, because their investments would be limited to minority stakes. In addition, MSICs would contribute stable equity financing, and the MSIC's decision to invest would itself be a credible signal to the market of a company's quality. ${ }^{41}$ The MSIC would thus serve to secure management's position in many circumstances, although its continued willingness to perform this function would depend entirely on its expert evaluation of management's performance.

From the corporate governance perspective, the MSIC's chief value would stem from its ability to monitor management's performance. As professionals charged with their employer's interests, MSIC directors would not only be financially independent of the management of portfolio companies, they would be financially dependent on shareholder interests. Thus, MSIC directors would possess precisely the incentive to monitor-and, if need be, to challenge-the policies of an unsuccessful management that outside directors now lack. Because MSIC board members would be experienced professionals able to devote their full attention to a small number of operating companies, they would possess the time, expertise, and support services necessary to monitor effectively. Finally, although MSICs would not attempt to dictate corporate policy or unilaterally displace unsuccessful managers, the

40. Gilson \& Kraakman, supra note 24, at 886-88. The recent aggressiveness of the outside directors at General Motors, American Express, and Westinghouse provides some reason for optimism. However, in all three cases, the boards acted only after a long period of poor performance. See, e.g., Bill Saporito, The Toppling of King James III, ForTUNE, Jan. 11, 1993, at 42; Thomas A. Stewart, The King Is Dead, ForTuNE, Jan. 11, 1993, at 34. Thus, the need for board reform remains.

41. Berkshire Hathaway's $14 \%$ stake in the total voting equity in Salomon, Inc. dramatically illustrates both the value of an MSIC-like investment as a source of stable capital, and the contribution that a large shareholder can make in stabilizing the market's perception of a firm in crisis. $C f$. note 99 infra (discussing Berkshire Hathaway's presence on the board of Salomon, Inc.). 
views of MSIC directors-backed by between 10 and 35 percent of a company's voting stock ${ }^{42}$-would likely carry the influence to force out an unsuccessful management team, even if it might lack the power to dictate a successor. ${ }^{43}$

Individual shareholders of both the MSIC and its portfolio companies would benefit directly from a successful MSIC strategy. MSIC shareholders would gain to the extent that MSIC monitoring increased the value of portfolio companies and, hence, the value of the MSIC. In addition, non-MSIC shareholders of portfolio companies would benefit from the increased value of the portfolio companies that would result from MSIC monitoring. ${ }^{44}$ This effect might be especially pronounced, moreover, because MSICs could be expected to invest only in companies where their business expertise and monitoring skills could be used to maximum advantage.

Even in a favorable regulatory climate, MSICs would hardly be a panacea for America's corporate governance problems, if only because their investments would be dwarfed by those of traditional financial investors, such as pension and mutual funds. The magnitude of MSIC investments would also be constrained by the availability of suitable investment candidates, and by the small number of companies that any single MSIC would be able to invite into a long-term partnership. Unlike the corporate raiders of the 1980s, MSICs would earn their returns the hard way: not from the rapid turnover of corporate assets, but from their operation, from the cultivation of sound management, and from productive efficiency. Thus, the typical MSIC portfolio might invest in only ten or fifteen companies over the course of a decade. ${ }^{45}$

Despite these limitations on their direct influence, the MSIC strategy could be expected to affect the entire corporate governance system indirectly, as a working demonstration of the value of highly motivated professional directors. Such directors would be particularly easy to recruit and compensate through the MSIC form. They would simply be the full-time

42. Jan Stenbeck recently suggested this range of holdings in a proposal to exempt MSICs from various provisions of the Investment Company Act of 1940, 15 U.S.C. $\$ 80 \mathrm{a}$ (1988 \& Supp. 1991). See Jan Stenbeck, Proposed Amendment of the Investment Company Act of 1940 to Facilitate Operations of Managerial Strategic Investment Companies, at B-1 (Feb. 1992) (unpublished manuscript, on file with the Stanford Law Review).

43. Even here, the minority character of the MSIC investment would require it to operate both collectively, through a coalition with traditional outside directors, and independently. Because such outside directors are quite effective when issues are framed for them, see LORSCH \& MACIVER, supra note 19, at 97-139, a conflict between MSIC directors and management might energize traditional outside directors, an important corporate resource, see Gilson, Gordon \& Pound, supra note 24, at 32-33.

44. Recall that such monitoring gains have been officially noted in Sweden. See Skog \& Isaksson, supra note 30 , at 26 . In addition, the American empirical literature, which we review in text accompanying notes 80-99 infra, suggests that public companies in which significant shareholders play an active management role perform systematically better than companies in which they do not. See notes 92-99 infra and accompanying text.

45. For example, the two relatively large Swedish MSICs discussed above presently hold only 10 and five companies respectively in their strategic portfolios. See AB INDUSTRIVÄRDEN, supra note 34 , at 14-15; KINNEVIK, supra note 34 , at 31 . 
MSIC employees designated to serve on the boards of portfolio companies. We have argued elsewhere ${ }^{46}$ that the real impediments to the use of professional directors by institutional investors in America are practical: American inexperience with the role of the professional director, the costs of recruiting and electing such directors, the frequently exaggerated legal risks to institutional investors that might arise from backing professional directors, ${ }^{47}$ and, finally, the simple absence of a model. The success of an American MSIC could reduce these costs by familiarizing institutional investors and corporate managers alike with the value of professional directors. Thus, successful American MSICs would encourage other institutional investors to pursue similar board-centered efforts to reform corporate governance.

In sum, a powerful corporate governance rationale exists for facilitating the MSIC form, quite apart from the novel investment opportunity that the MSIC would create for public investors. A successful MSIC strategy would directly benefit the managers and shareholders of public companies in which MSICs invested by providing long-term capital, business expertise, and a guardian shareholder to monitor management's performance. In addition, successful MSICs would have much to teach other institutional investors about the monitoring capabilities of the board and the value of highly motivated professional directors. ${ }^{48}$

\section{REgUlatory OBSTACLES TO THE MSIC FORM}

An obvious question arises from our conclusion that the MSIC form not only fits the American framework of corporate governance, but also provides a plausible market response to the agency costs of that framework: Why are there no American MSICs? We find much of the answer in the legal obstacles created by the Investment Company Act of 1940 (the "1940 Act") 49 and its associated regulations. ${ }^{\text {so }}$

46. Gilson \& Kraakman, supra note 24.

47. Id. at 894-905 (discussing the legal risks); see also Black, supra note 2, at 530-66 (surveying the full range of regulatory barriers to electing professional directors).

48. We are not alone in suggesting that MSIC-like institutions can be introduced in new jurisdictions. The potential for financial intermediaries to play the role of guardian shareholder has figured prominently in proposals concerning the institutional structure of privatization in Eastern Europe. See, e.g., Roman Frydman \& Andrzej Rapaczynski, Markets and Institutions in LargeScale Privatization: An Approach to Economic and Social Transformation in Eastern Europe, in RE-

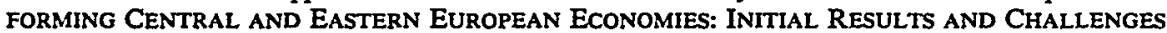
253, 262-67 (Vittorio Corbo, Fabrizio Coricelli \& Jan Bossak eds., 1991); David Lipton \& Jeffrey Sachs, Privatization in Eastern Europe: The Case of Poland, in REFoRMING CENTRAL AND EASTERN EUROPEAN ECONOMIES, supra, at 231, 240-42.

49. 15 U.S.C. $\$ 80$ a (1988 \& Supp. 1991).

50. The Internal Revenue Code creates further regulatory obstacles to the formation of American MSICs. Subchapter $M$ provides investment companies which meet its requirements with favorable pass-through tax status-that is, only the investors, and not the investment company, are taxed on dividends received by the investment company and on capital gains. A company can only attain this status if it satisfies specific diversification requirements intended to deny "special treatment to companies which undertake to control the enterprises in which the bulk of their funds are placed." H.R. REP. No. 586, 82d Cong., Ist Sess. 34 (1951). A nonqualifying MSIC's dividend income would be taxed at an effective rate of $10 \%$, its capital gains might be taxed at $34 \%$, and distributions from the MSIC to its investors would be taxed again at ordinary rates. See Mark J. 
As Mark Roe has argued, the 1940 Act is one of the half-dozen major federal statutes that methodically disables financial investors from major participation in corporate governance. ${ }^{51}$ The Act's broad definition of "investment company" includes, inter alia, any issuer of securities that holds more than 40 percent of its assets in the form of investment securities. ${ }^{52}$ All investment companies, in turn, are regulated by the Act unless they qualify for an express "exception" or an exemption. An American MSIC could not escape the Act's provisions on either ground. In particular, as a publiclytraded investment company, an MSIC would be ineligible for the private investment company exception; ${ }^{53}$ and as an investment company holding minority stakes in portfolio companies rather than exercising outright control, an MSIC would not qualify for the so-called holding company excep-

Roe, Political Elements in the Creation of a Mutual Fund Industry, 139 U. PA. L. REv. 1469, 1479 (1991). The potential for such double taxation undoubtedly handicaps the MSIC form, but it is less preclusive than the 1940 Act provisions described infra, because the MSIC can avoid much of the impact of double taxation through its investment strategy, although at some cost in restricted investment scope. Roe argues that these restrictions are unjustifiable even if they are only costly, but not preclusive. Id.

First, the MSIC could invest in portfolio companies that do not pay dividends (using its influence to assure the continuation of that policy) and retain those investments for the long term. The former eliminates the dividend tax at the MSIC level; the latter defers any capital gains tax, thereby reducing the present value of the double taxation of capital gains. Of course, investing for the long term is not just a tax driven strategy for MSICs, but their very goal.

Second, an MSIC could qualify for favorable tax treatment without too significant a restriction on its core investment strategy. I.R.C. \& 851(b)(4) (1992) restricts pass-through taxation to companies that satisfy two diversification standards. The first requires that $50 \%$ of an MSIC's investments be in securities, which, with respect to any issuer, exceed neither 5\% of the MSIC's total assets, nor represent more than $10 \%$ of the outstanding voting stock of the issuer. I.R.C. $\$ \S 851(b)(4)(A)(i)-$ (ii). Thus, an MSIC could invest $50 \%$ of its assets in acquiring $10 \%$ of the voting stock of each of 10 companies and still meet the Code's requirements. The second requires that an MSIC invest no more than $25 \%$ of its assets in any single issuer. I.R.C. $\$ 851(\mathrm{~b})(4)(B)$. Thus, an MSIC could use $50 \%$ of its assets to purchase large-block (or even controlling) stock positions in portfolio companies so long as no single large-block position represented more than $25 \%$ of its total assets.

To be sure, complying with $\S 841$ (b)'s diversification requirements does restrict an MSIC's investment strategy, but not seriously. For example, an MSIC could invest $50 \%$ of its assets in $10 \%$ positions in 10 companies, and $50 \%$ of its assets in $25 \%$ to $40 \%$ positions in a few additional companies. Such a portfolio is very similar to those maintained by the Swedish MSICs. See AB INDUSTRIVÄRDEN, supra note 34, at 14-15; KINNEVIK, supra note 34, at 31. The principle restriction, in addition to limiting MSIC large-block positions to $50 \%$ of its assets, is limiting the relative size of the companies in which large-block positions are taken to 25\% of an MSIC's assets.

For a more pessimistic view of the impact of $\S 851$ (b)'s restrictions, see Roe, supra, at 1479.

51. See Roe, supra note 50, at 1503-07.

52. 15 U.S.C. $\$ 80 \mathrm{a}-3(\mathrm{a})(3)$ (1988).

53. See 15 U.S.C. $\$ 80 a-3$ (c)(1), which excepts from the 1940 Act's coverage investment companies that are beneficially owned by fewer than 100 persons. Traditionally, this exception has allowed small numbers of wealthy individual and institutional investors to pursue MSIC-like investment strategies. Given the large holdings of institutional investors, the absence of larger numbers of "private" MSICs is puzzling. For present purposes, it is sufficient to note two limiting factors: the widespread commitment of institutions to very broadly diversified portfolios comprised of many hundreds of stocks; and a reluctance, currently diminishing, to involve themselves in control related investments. Recent efforts to create private MSIC-like vehicles, such as Allied Investment Partners and the Lens Fund, suggest slow change. See Morton Paulsen, Monks Sets His Sights on Sears: Corporate Gadfly's "Lens Fund" Targets "Underachievers", 6 TURNAROUNDS \& WorkouTS, June 15, 1992, at 1; Randall Smith \& James A. White, White-Squire Fund Boasts Old Boys and White Shoes, WAll ST. J., Nov. 1, 1991, at C1. 
tion to the Act's coverage. ${ }^{54}$

Because the provisions of the 1940 Act apply, an American MSIC would be forced to comply with a comprehensive and highly technical set of substantive regulations designed to protect naive participants in the very different investment vehicles of a mutual fund or diversified closed-end investment fund. Although none of these provisions explicitly precludes an American MSIC, they impose numerous costs and rigidities that effectively achieve the same result. Only a lengthy exegesis of the 1940 Act could do justice to all of the obstacles that it creates..$^{55}$ Several representative examples, however, should suffice to establish the 1940 Act's prohibitive effect.

Consider first the problem of compensating managers of MSICs who would also serve as directors of portfolio firms. Since these managers would add value by serving as high-level monitors, MSIC investors might prefer performance-based compensation schedules closely tied to increases in the value of the MSIC itself. However, the 1940 Act bars the logical elements of such a compensation plan. Under the Act, an MSIC could neither issue long term stock options nor award its managers with equity securities of any sort in exchange for their services. ${ }^{56}$ A compensation restriction designed to protect investors in passive investment funds from dilution by insiders would thus preclude the most common incentive compensation devices found outside the topsy-turvy world of investment companies.

Even more serious impediments to MSICs are contained in the 1940 Act's many restrictions on the ability of investment companies to raise new capital or make distributions. Section $23(\mathrm{~b}),{ }^{57}$ which bars closed-end investment companies from issuing equity at a price below net asset value, would make it extremely difficult for an MSIC to raise additional equity capital on the market apart from its initial public offering. For reasons that remain poorly understood, shares in closed-end investment companies-a category that would include American MSICs ${ }^{58}$ - tend to trade at a discount to the

54. Under Rule 3a-1(a)(4), the securities of a portfolio company controlled by an investment company, whether by virtue of holding a majority of voting equity or otherwise, do not count as investment securities for purposes of determining jurisdiction of the 1940 Act. Rule 3a-1(a)(4), 17 C.F.R. $\S 270.3 a-1(a)(4)$ (1992). The paradoxical result is that the 1940 Act exempts control blocks and holding companies from regulation, while systematically disfavoring the MSIC strategy of exercising influence on the governance of portfolio companies through large-block minority holdings. This represents another instance in which federal securities regulations favor acquisitions of control over efforts to acquire minority positions. See Gilson, Gordon \& Pound, supra note 24, at 33-42.

55. The Stenbeck proposal to amend the 1940 Act to facilitate American MSICs requests exemption from no fewer than 15 of the Act's central provisions. See Stenbeck, supra note 42, at C-2 to C-3. A parallel analysis of how, prior to 1980 , the Act precluded publicly-traded venture capital funds from investing in start-up companies may be found in commentary on the 1980 Amendments. See, e.g., Reginald L. Thomas \& Paul F. Roye, Regulation of Business Development Companies Under the Investment Company Act, 55 S. CAL. L. Rev. 895, 906-10 (1982). These Amendments were adopted expressly to facilitate public venture capital financing of start-up firms (termed "business development companies" in 15 U.S.C. $\$ 80-2(a)(48)(1988)$ ).

56. 15 U.S.C. $\S 80 \mathrm{a}-18(\mathrm{~d}), 23(\mathrm{a})$.

57. 15 U.S.C. $\$ 80 a-23(b)$.

58. The 1940 Act divides investment companies into closed-end and open-end companies for regulatory purposes. 15 U.S.C. $\S 80 \mathrm{a}-5(\mathrm{a})$. Open-end companies are mutual funds whose investors 
pro rata value of their portfolio securities. ${ }^{59}$ The bar against issuing new equity at prices below net asset value, then, would predictably operate as a bar against new equity offerings by most MSICs most of the time. ${ }^{60}$ Once again, a rule without serious consequences for passive investment funds might well cripple an MSIC in search of new opportunities for active investment.

The 1940 Act's restrictions on new equity capital are exacerbated by equally draconian limitations on debt financing. Under section 18(a) of the 1940 Act, ${ }^{61}$ an MSIC is prohibited from issuing any senior securities unless it could pass an asset coverage test of at least 300 percent in the case of debt securities, and 200 percent in the case of preferred stock. In addition, section 18(c) restricts MSICs to a single class of debt securities. ${ }^{62}$ As a consequence, an American MSIC would be forced to depend almost entirely on its initial equity offering, rights offerings to existing shareholders, voluntary reinvestment of dividends, and bank loans for new financing. The option of long-term debt financing, which would permit the MSIC to exploit new investment opportunities without diluting existing shareholders, would be largely foreclosed. ${ }^{63}$

The 1940 Act would be equally inhospitable if MSIC managers wished to make periodic redemptions or repurchases to combat the discounts that are endemic to closed-end investment companies. Section $23(c)^{64}$ tightly regulates repurchases of shares by closed-end investment companies. The SEC's Division of Investment Management recently acknowledged that the most effective method of repurchase-periodic tender offers-is particularly cumbersome for closed-end investment companies. ${ }^{65}$ But tender offers are costly even outside the highly regulated world of investment companies. The interactions between the 1940 Act and tender offer regulation would make tender

may redeem their interests at net asset value. By contrast, closed-end companies, like ordinary corporations, issue shares that may be traded but not redeemed.

59. Such discounts are not only well documented for American closed-end investment companies, but appear to affect Swedish MSICs as well. See KINNEvIK, supra note 34, at 6; see also notes $86 \& 89$ infra and accompanying text.

60 . Indeed, $\S 23$ (b) has precisely this effect today, barring new equity offerings by diversified closed-end investment companies. See 2 Thomas Lee HAZEN, TreatiSE ON THE LAW OF SecuriTIES REgulation $\S 17.5$ ( $2 \mathrm{~d}$ ed. 1990). The limited exception consists of rights offerings by the small number of funds trading at a premium to their net asset value. In these offerings, existing shareholders get the opportunity to purchase new shares at a discount to net asset value. See William Power, Gabelli Asks Investors for More, Again. WALl St. J., Sept. 25, 1992, at C1.

61. 15 U.S.C. $\$ 80 \mathrm{a}-18(\mathrm{a})(1)(\mathrm{A}), 2(\mathrm{~A})$.

62. 15 U.S.C. $\S 80 \mathrm{a}-18$ (c). The 1940 Act provides some flexibility insofar as bank loans and other privately-negotiated debt are not deemed "securities" for purposes of the single issue rule, though they must be included in asset coverage calculations. Id.

63. The Swedish experience demonstrates the importance of this barrier to debt financing. During the period 1978-1988, Swedish MSICs issued essentially no new stock, financing the increase in their holdings with borrowings. Skog \& Isaksson, supra note 30, at 8.

64. 15 U.S.C. \& 80a-23(c).

65. Division of Investment Management, Securities and Exchange Commission, Protecting Investors: A Half-Century of InVestment Company Regulation 440-41, reprinted in Extra Edition No. 1504, Fed. Sec. L. Rep. (CCH) (May 29, 1992). 
offers still more costly for MSICs. ${ }^{66}$

As a final illustration of the regulatory barriers to an American MSIC, consider the broad and ambiguous conflict-of-interest rules imposed on investment companies by the 1940 Act. To deter self-dealing by investment company insiders, the 1940 Act bars purchases and sales of securities between an investment company and its promoter, underwriter, affiliates, or affiliates of its affiliates-subject to a lengthy determination by the SEC that the proposed transaction would be "fair" to the shareholders of all companies involved. ${ }^{67}$ Under the 1940 Act, the affiliates of an investment company include not only its directors, employees, controlling person, and holders of more than 5 percent of its voting equity (or "upstream affiliates"), but also portfolio companies in which the investment company holds more than 5 percent of voting equity (or "downstream affiliates"). 68 For good measure, Rule 17d-1, promulgated under the 1940 Act, also bars joint arrangements or enterprises between investment companies and affiliated persons that are undertaken without prior SEC authorization. ${ }^{69}$ Uncertainty remains regarding the precise reach of these conflict-of-interest prohibitions, however, because more recent exemptive rules narrow their scope in complex ways. ${ }^{70}$

If the protection of the Commission's exemptive provisions were withheld, the 1940 Act's conflict-of-interest rules would cut especially deeply against a prospective American MSIC. Virtually any exchange of shares between an MSIC and one of its portfolio companies, or an affiliate of either firm, would require advance authorization by the SEC. Thus, any buyout, issuer repurchase, or share conversion-in addition to a simple effort by an MSIC to provide a needy portfolio company with additional capital一would be subject to regulatory veto and lengthy delays. Strategic investments by an MSIC portfolio company, such as the acquisition of a rival firm, would risk running afoul of the proscription against joint enterprises between the MSIC and its affiliates. Indeed, even placing MSIC directors on the boards of portfolio companies-the core feature of the MSIC strategy-might constitute a joint arrangement requiring SEC authorization, and, at the very least, would greatly increase the risk that major investment decisions by the portfolio company would do so. ${ }^{71}$

66. Note, however, that the costs of employing periodic tender offers to make repurchases, while still substantial, have been reduced within the last year. A recent SEC release reversed the Commission's long-standing view that any program of periodic tender offers poses serious fiduciary problems for investment company directors. Investment Company Act Release No. 19115, app. C [1992 Transfer Binder] Fed. Sec. L. Rep. (CCH) \ 85,063 (Nov. 20, 1992); cf. Division OF INVESTMENT MANAGEMENT, supra note 65, at 443 n.88 (criticizing the SEC's prior opposition to tender offers). In addition, the newly proposed rules would, if adopted, further facilitate periodic repurchases by closed-end funds. See Investment Company Act Release No. 18869, [1992 Transfer Binder] Fed. Sec. L. Rep. (CCH) I 85,022 (July 28, 1992).

67. See 15 U.S.C. $\S 80 \mathrm{a}-17$ (a)(1), (a)(2), (b)(1).

68. 15 U.S.C. $\$ 80-2$ (a)(3); see also HAZEN, supra note 60, § 17.7; The Application of Section 17 of the Investment Company Act of 1940 to Portfolio Affiliates, 120 U. PA. L. REV. 983, 985-86 (1972).

69. Rule 17d-1(a), 17 C.F.R. $\$ 270.17$ d-1(a) (1992).

70. See Rule 17a-6, 17 C.F.R. § $270.17 a-6$ (1992); Rule 17d-1(d)(5), 17 C.F.R. § 270.17d1(d)(5) (1992).

71. Rule 17d-1(a) bars an affiliate of an investment company from "participat[ing] in, or ef- 
Due to these onerous requirements for advance authorization and fairness review, the MSIC form would not likely survive if the 1940 Act's transactional and joint enterprise restrictions applied to transactions between MSICs and portfolio companies. The issue thus becomes whether the SEC's overlay of exemptive provisions might remove MSICs from the authorization requirement. At first glance, the exemptive rules (specifically Rules $17 a-6$ and $17 d-1(d))$ appear promising because they are targeted at insulating the "downstream relationship" between investment companies and portfolio affiliates from regulatory interference. On closer inspection, however, it becomes apparent that great uncertainty remains as to the reach of these exemptions: in particular, any attempt to compensate MSIC officers on the basis of portfolio company performance would seem to jeopardize the availability of the exemptions. ${ }^{72}$ Thus, the 1940 Act's harsh conflict-of-interest rules, and the ambiguity surrounding the ameliorative provisions that purport to weaken these rules, comprise a formidable, if not fatal, obstacle to the MSIC form. ${ }^{73}$

fect[ing] any transaction in connection with, any joint enterprise or other joint arrangement or profit-sharing plan" in which the investment company is also a "participant," without first obtaining SEC authorization. 17 C.F.R. $\$ 270.17 d-1$ (a). This notoriously ambiguous language is usually construed to refer to transactions with third parties in which both the investment company and its affiliated portfolio company participate. See, e.g., Milton P. Kroll, The "Portfolio Affiliate" Problem, in 3 ANNUAL INSTITUTE ON Securities REgulation 261, 283-86 (Robert H. Mundheim \& Arthur Fleisher, Jr. eds., 1972). However, any construction of the rule would be possible in the unprecedented circumstance in which an MSIC's employees participated as directors in the business decisions of a portfolio affiliate. More particularly, the portfolio affiliate-or any of its major transactions with third parties-might be deemed to be a "joint enterprise." Alternatively, the compensation arrangements between the affiliate and its MSIC directors might be so characterized. The flexible language of the Rule imposes very few limitations on SEC intervention.

72. For example, Rule 17a-6 exempts from $\S 17$ (a) of the 1940 Act a transaction between an investment company and an affiliated portfolio company, providing, inter alia, that no investment company insiders (including officers, directors, and promoters) act as parties to the transaction or have a "direct or indirect financial interest" in a party to the transaction. Rules 17a-6(a)(1) \& 17a6(a)(5)(ii), 17 C.F.R. $\S \S 270.17 a-6(a)(1), 270.17 a-6(a)(5)(i i)$. Officers of MSICs who receive contingent compensation based on the performance of a portfolio company (and who serve as a director of a portfolio company) might have a sufficient financial interest in the MSIC or the portfolio company to cost the MSIC its Rule 17a-6 exemption. Cf. Narraganset Capital Corp., Investment Company Act Release No. 11,018, 1980 WL 29383, at *3 (S.E.C. Jan. 14, 1980) (Rule 17a-6 exemption unavailable to investment company when one director has indirect financial interest as salaried officer of portfolio company). Similarly, Rule 17d-1(d) amends the joint enterprise rule currently formulated in Rule 17d-1(a) to exempt joint enterprises in which no investment company insider has "a financial interest, direct or indirect." Rule 17d-1(d)(5)(i), 17 C.F.R. § 270.17d-1(d)(5)(i). Once again, the question arises: When might the performance-based compensation of an MSIC officer trigger the financial interest test, and thus foreclose the exemption, in the course of a "joint enterprise" between an MSIC and a portfolio affiliate? Cf. Narraganset Capital Corp., 1980 WL 29383, at *4 (Rule 17d-1(d)(5) exemption unavailable to investment company when one director has indirect financial interest as salaried officer of portfolio company). Indeed, it appears that a contingent compensation arrangement between an MSIC and one of its officers would itself be a "joint transaction" outside the scope of the Rule's exemptive provision, even apart from a transaction involving a portfolio affiliate. See R. James Gromley, On the Same Side of the Table: Is Investment Company Act Rule 17d-1 Partly Invalid?, 20 SEC. REg. L.J. 115, 117-18 (1992).

73. Consider this recent observation regarding Rule 17d-1:

In analyzing the difficulties of "portfolio affiliates" of investment companies under Section 17(d), a lawyer experienced with the Investment Company Act described the section and rule as "a morass of unascertainable depth," and referred to the SEC's own acknowledge- 
Although this sampling of the regulatory barriers raised by the 1940 Act is hardly exhaustive, ${ }^{74}$ it demonstrates that the 1940 Act itself can explain the absence of American MSICs. ${ }^{75}$ As additional evidence, consider the three classes of American firms that come closest to pursuing an MSIC investment strategy. First, private investment companies make MSIC-like investments in public corporations. ${ }^{76}$ But the 1940 Act bars such firms from the public capital markets, so they remain closed to all but a handful of wealthy investors. Second, business development corporations (or "BDCs") are permitted to raise public funds for active MSIC-like investments in startup corporations. ${ }^{77}$ But BDCs are restricted to venture capital opportunities, and have flourished only since 1980, when Congress expressly exempted them from the most onerous provisions of the 1940 Act. ${ }^{78}$ Finally, Warren Buffett's famous investment vehicle, Berkshire Hathaway Inc., is the closest existing approximation of a publicly-traded American MSIC. But Berkshire Hathaway escapes the 1940 Act only by folding its strategic investment activities into an insurance subsidiary, and exploiting Nebraska's permissive insurance statute in a fashion that no other company can be expected to duplicate. ${ }^{79}$

ment of "the uncertain standards under 17(d)." His ultimate legal advice was "prayer consistently applied"!

Gromley, supra note 72, at 116-17 (citations omitted). Prayer may suffice to resolve the legal problems of conventional investment companies, but it is hardly a secure foundation for launching a new investment form such as the MSIC.

74. See Letter from Jan Stenbeck to Jonathan G. Katz, supra note 35. One especially serious additional obstacle to an American MSIC is the 1940 Act's ban on circular ownership. This ban would force an MSIC to divest its shares in a portfolio affiliate within a year after a portfolio company purchased more than $3 \%$ of the MSIC's shares. 15 U.S.C. $\$ 80 \mathrm{a}-20$ (c), (d). The management of any portfolio affiliate would be able to sever its ties to an MSIC at will, merely by buying a small block of the MSIC's shares. The threat of forced divestment would deter an MSIC from attempting to discipline the management of a portfolio company, no matter how poor the management's performance.

75. A final type of barrier presents more risk to Swedish than to American MSICs. A few states have adopted antitakeover statutes that obligate a shareholder whose ownership exceeds a specified ceiling, always less than a majority, to make an offer to purchase all the remaining shares at a formula price. See, eg., 15 PA. Cons. STAT. ANN. \$§ 2541-2548 (1992). While the goal of such statutes was to discourage creeping takeovers, their effect is to bar an MSIC-type ownership structure in companies subject to the restriction. While an American MSIC could avoid such statutes by not investing in companies incorporated in the small number of jurisdictions in which they have been adopted, existing Swedish MSICs face a much more serious threat. The European Commission's Proposed Thirteenth Directive contains such a mandatory bid requirement that triggers upon acquisition of not more than one-third of the voting rights in a company. See Amended Proposal for a Thirteenth Council Directive on Company Law Concerning Takeovers and Other General Bids, art. 4, 1991 O.J. (L 240) 4-5. If the directive is adopted, Swedish MSICs face a serious problem should Sweden join the European Community.

76. See, e.g., Smith \& White, supra note 53 , at $\mathrm{C} 1$.

77. See note 55 supra.

78. 15 U.S.C. $\$ \S 80 \mathrm{a}-2(\mathrm{a})(48), 80 \mathrm{a}-54$.

79. See Roe, supra note 2, at 23 n.53 (describing the unique legal structure of Berkshire Hathaway). The 1940 Act exempts insurance companies from its provisions. 15 U.S.C. $\$ 80 \mathrm{a}$ 3(c)(3). 


\section{OBJECTIONS TO AMERICAN MSICS}

Even if the current provisions of the 1940 Act effectively bar American MSICs, it does not necessarily follow that MSICs would thrive in the absence of the 1940 Act, or indeed, that they should be permitted to thrive. Three possible objections to MSICs remain, notwithstanding the MSIC's promise as a device for mitigating the governance costs of American corporations. First, the American regulatory scheme reflects a deep-seated concern that active financial investors, like MSICs, might somehow injure the interests of other passive public investors. Second, the perennial problem of discounts on closed-end investment companies creates an attendant concern that whatever value MSICs might add to their portfolio companies would be lost to MSIC shareholders and other public shareholders of portfolio companies. Finally, the fundamental question remains whether MSICs, as largeblock shareholders, might fail to add real value to their portfolio companies.

\section{A. Non-MSIC Shareholders of Portfolio Companies}

Concern about the risks posed to public investors by active financial investors has been a deep-seated and recurrent theme in the politics of American regulation, including the regulation of investment companies. ${ }^{80}$ What distinguishes investment companies in general (and MSICs in particular) from other financial institutions is that they are pure equity investors. They fit perfectly within the one-dimensional American governance pattern, because their sole interest is in investment returns and their sole relationship to their portfolio companies is that of a shareholder/principal. Thus, MSIC investments would present few, if any, of the conflicts of interest that would accompany active investments by other institutional investors, such as commercial banks, pension funds, or insurance companies. ${ }^{81}$ It follows that MSICs should escape much of the traditional antipathy toward active financial investors, here based on a fear of conflicts of interest that might harm other shareholders. Moreover, given the low turnover and long-term nature of MSIC investments, even fears of second-order conflicts of interest such as insider trading by MSICs would seem to be misplaced. ${ }^{82}$

Far from triggering the usual suspicions about financial investors, the MSIC would seem to be the model monitor within the one-dimensional American governance framework. Only foolish uses of MSIC influence

80. For an extensive analysis of the role of this concern in the drafting of the 1940 Act and subsequent tax legislation, see Roe, supra note 50, at 1471-74, 1484-94.

81. See id. at 1503-04 (presenting potential conflicts of interest facing non-MSIC, nonmutual fund institutions).

82. Concern about the conflicts of interest inherent in a multidimensional monitoring relationship motivates much of the criticism of the role of universal banks in German corporate governance, as well as the role of main banks in Japanese governance. See BAUMS, supra note 9, at 25-26; Gilson \& Roe, supra note 12, at 879-82; Köndgen, supra note 9, at 23-25. One approach to minimizing the risk of conflict of interest without giving up the advantages of a multidimensional monitoring structure is to focus on the areas where the conflict of interest is most pronounced. For example, one might prohibit proxy voting by German banks in the absence of specific shareholder instruction when the subject of the election concerns control. 
could harm other shareholders in its portfolio companies, for example, needless interference with sound management decisions. Yet, such misguided activism would be powerfully deterred because it would soon put the MSIC itself out of business. Moreover, precisely because the MSIC would be a minority shareholder, and would thus exercise only influence not outright control, the MSIC might not have sufficient influence itself to be able to trump the business decisions of a successful management team. ${ }^{83}$

\section{B. The Problem of Discounts}

A more subtle problem is the risk that MSICs might fail to reward their own shareholders, as a consequence of the perennial market discounts that dog closed-end investment companies. Shares in closed-end investment companies commonly trade at a discount to net asset value for reasons that continue to elude financial economists, but appear to be unrelated to the quality of company management. ${ }^{84}$ Although such discounts now average between 1 and 10 percent of net asset value, they have reached 20 percent and higher in previous five year periods. ${ }^{85}$ The Swedish experience provides good reason to expect the discount phenomenon to affect American MSICs at least as much as it currently affects diversified closed-end investment companies. ${ }^{86}$ Indeed, to the extent that American MSICs fail to qualify for the same pass-through tax treatment that diversified investment companies enjoy, ${ }^{87}$ MSIC discounts might even be larger than existing discounts on closed-end funds. It is fair to ask, then, whether such discounts might make American MSICs unattractive investments, even without the regulatory barriers imposed by the 1940 Act. Or, to put the question differently: Would shareholders refuse to invest in MSICs if they could avoid the MSIC discount by investing directly in the MSIC's portfolio corporations?

Both questions may be answered negatively, provided that the value added by the MSIC to its portfolio companies exceeds the discount on the shares of the MSIC. Consider the life cycle of a successful MSIC that is capable of augmenting the value of its portfolio of active investments by, say,

83. See note 43 supra.

84. See Reinier Kraakman, Taking Discounts Seriously: The Implications of "Discounted" Share Prices as an Acquisition Motive, 88 CoLuM. L. Rev. 891, 902-05 (1988) (surveying finance literature on explanations for closed-end fund discounts); Kathleen Weiss, Kenneth Lehn \& David Malmquist, Office of Economic Analysis, Securities and Exchange Commission, The Post-Offering Price Performance of Closed-End Funds (July 21, 1989) (unpublished manuscript, on file with Stanford Law Review). A novel recent effort to explain discounts relies on noise trading by small investors and the attendant market risk that small investors introduce into the pricing of closed-end fund securities. See J. Bradford De Long \& Andrei Shleifer, Closed-End Fund Discounts: A Yardstick of Small Investor Sentiment, J. PorTfolio MGMT., Winter 1992, at 46. Persistent discounts are presently a major concern of SEC investment company regulation. See DIVISION OF INVESTMENT MANAGEMENT, supra note 65 , at $432-42$.

85. See Kraakman, supra note 84 , at 903.

86. For example, prior to 1989 , shares in the Swedish MSIC Kinnevik had been historically priced at between $60 \%$ and $80 \%$ of net asset value. KINNEVIK, supra note 34, at 97 . Notwithstanding this heavy discount, Kinnevik significantly outperformed the Swedish market during the $1980 \mathrm{~s}$ as a consequence of the rapidly increasing value of its portfolio. Id. at 4-5.

87. See note 50 supra. 
50 percent over a ten year holding period, but is subject to an average market discount of 10 percent. If the MSIC is capitalized with an initial public offering, its original shareholders will predictably suffer a 10 percent market loss-the MSIC's market discount-relative to the market value of the equity stakes that the MSIC purchases for its portfolio. ${ }^{88}$ However, as the value of the monitoring services that the.MSIC provides becomes apparent in the improved performance of its portfolio companies, the prices of shares in these companies will rise until they fully reflect the value of the MSIC's contribution. By hypothesis, the MSIC's shares will always trade at a price that averages 10 percent less than the pro rata value of its portfolio. Yet, an original investor in the MSIC who holds her shares long enough for the market to recognize the improved performance of the IMSIC portfolio will realize a 40 percent gain. It is highly unlikely this same investor could have reaped the full 50 percent gain merely by mimicking the MSIC's investment choices for the simple reason that, immediately upon announcement of the MSIC's investment decisions, the share prices of its portfolio companies should already reflect much of the prospective value of the MSIC's monitoring contributions.

It follows that the likelihood of discounts alone need not make an American MSIC unattractive to investors. Some Swedish MSICs have performed extremely well in the face of continuous large discounts. ${ }^{89}$ At most, an expected discount establishes a floor for the value that the MSIC must add to its portfolio companies in order to remain a profitable venture for public investors.

\section{Can MSICs Add Sufficient Value in the American Market?}

Given that American MSICs could succeed if they were able to add sufficient value to their portfolio companies, the final issue is whether MSICs can be expected to realize important monitoring gains. Here, there can be no guarantees. Nevertheless, both anecdotal and systematic evidence suggest that, with competent management, publicly-held MSICs would enjoy a reasonable chance of generating the requisite gains. The anecdotal evidence includes the proven track record of Berkshire Hathaway ${ }^{90}$ and the continuing efforts of privately-held investment companies to pursue MSIC-like investment strategies beyond the reach of the 1940 Act. While data on the performance of private MSICs is unavailable, such companies do appear to enjoy the confidence of sophisticated investors in the American market. ${ }^{91}$

The systematic evidence favoring the MSIC strategy is the same evidence

88. See Weiss, Lehn \& Malmquist, supra note 84 , at 4 (reporting an average $15 \%$ discount within 120 days of initial public offerings of closed-end equity funds).

89. See, e.g., KINNEVIK, supra note 34, at 6 .

90. See Berkshire Hathaway Inc., 1991 AnNual Report 4, 32 (1991).

91. See, e.g., Smith \& White, supra note 53, at C1 (Allied Investment Partners L.P. to "buy friendly stakes of $5 \%$ to $20 \%$ in about a dozen public companies with subpar records" and present four "industrialists" to serve as expert directors on portfolio company boards). But cf. note 99 infra (Corporate Partners, another "white squire" fund, has experienced mixed investment results). 
that supports the case for institutional monitoring in general. Bernard Black aptly characterizes it as "modest, but not conclusive," 92 as it must be, given the paucity of systematic efforts to introduce monitoring reforms of any sort. Following Black's typology, the most salient evidence from the American market falls into three categories: (1) studies investigating the link between corporate value and concentrated ownership; (2) the analogy to leveraged buyouts; and (3) data on the effects of institutional monitoring.

The evidence on the effects of concentrated ownership on corporate performance is difficult to interpret, because none of the commonly used proxies for evaluating performance is entirely satisfactory. Nevertheless, the overall pattern of results from the concentration studies points in the right direction. Studies of Tobin's q-the ratio of the replacement value of a company's assets to the market value of its equity-generally show a positive correlation between Tobin's q (interpreted as a proxy for performance) and the size of ownership blocks held by corporate insiders, for ownership blocks ranging from 0 to 5 percent. ${ }^{93}$ For blocks between 5 and 20 percent, the relationship between Tobin's $q$ and increasing ownership is less clear, although most studies find that greater ownership is associated with improved performance when insider holdings approach 20 to 25 percent of a company's voting equity, the average stake that an MSIC would likely hold in a portfolio company. ${ }^{94}$ In addition, studies of other proxies for corporate performance, such as earnings to price ratios and accounting profits, often find a positive relationship to ownership concentration, despite some mixed results. ${ }^{95}$

Taken together, the ownership studies suggest a mildly positive relationship between active large-block shareholders and corporate performance. This result hardly guarantees the success of the MSIC strategy. Nevertheless, any favorable relationship between ownership and corporate performance is encouraging, given our imperfect measures of performance, and more importantly, the likely differences between MSICs and other large-block holders. Where today's typical inside blockholder is usually a company founder, his scion, or another operating company that may also have trade links to the portfolio company, MSICs would invest selectively in companies

92. Bernard S. Black, The Value of Institutional Investor Monitoring: The Empirical Evidence, 39 UCLA L. REV. 895, 917 (1992).

93. Id. at 918 \& nn.97-98 (citing studies on Tobin's q).

94. Thus, Randall Morck, Andrei Shleifer, and Robert Vishny report a positive correlation between Tobin's $q$ and holdings in the $0 \%$ to $5 \%$ range and beyond the $25 \%$ level, with a slight negative correlation between 5\% and 25\%. Randall Morck, Andrei Shleifer \& Robert W. Vishny, Management Ownership and Market Valuation: An Empirical Analysis, 20 J. FIN. EcoN. 293, 311-13 (1988). Hermalin and Weisbach report a significant positive correlation between Tobin's q and the size of CEO holdings in the 5\% to 25\% range. Hermalin \& Weisbach, The Effect of Board Composition and Direct Incentives on Corporate Performance, J. FiN. (forthcoming 1992). John McConnell and Henri Servaes report a similar relationship between Tobin's $q$ and the joint effects of insider holdings, large outsider holdings, and institutional holdings (but not insider holdings alone) over the $5 \%$ to 25\% range. John J. McConnell \& Henri Servaes, Additional Evidence on Equity Ownership and Corporate Value, 27 J. FIN. ECON. 595, 609 (1990); see also Black, supra note 92, at 918 \& nn.97-98 (citing studies on Tobin's q).

95. See Black, supra note 92 , at 918-20 \& nn.100-111 (citing studies). 
with the most to gain from expert monitoring. ${ }^{96}$ In addition, MSICs would presumably enjoy other important advantages over family blockholders, such as superior risk-bearing ability and monitoring expertise.

For these reasons, the MSIC strategy might be better evaluated from the perspective of Bernard Black's analogy to leveraged buyouts (where professional monitors also choose their companies carefully), than from the perspective of a more generalized connection between performance and ownership structure over all companies. Moreover, the data on leveraged buyouts are far more encouraging for MSICs. Numerous studies indicate that the LBOs of the 1980s made significant improvements in corporate performance on a number of dimensions, at least through 1986.97 The parallel evidence is less impressive for Black's third category of studies on the effects of monitoring by institutional investors. ${ }^{98}$ But this is hardly surprising, given the traditionally weak monitoring role of institutional investors. One would expect the monitoring intensity of MSICs to fall somewhere between institutional investors and LBO syndicates. However, between these two poles, the MSIC would more nearly resemble the LBO syndicate, both in its

96. The differences between an MSIC and existing blockholders as a proxy for MSICs likely explain the few empirical studies that suggest a negative relation between the presence of blockholders and portfolio company performance. Michael Barclay, Clifford Holderness, and Jeffrey Pontiff examine a peculiar subset of blockholders-those holding large minority positions in diversified closed-end investment companies. They report that cross-sectional discounts from net asset value appear to be significantly larger for funds with a large blockholder than for funds without such a holder. Michael J. Barclay, Clifford G. Holderness \& Jeffrey Pontifi, Private Benefits from Block Ownership and Discounts on Closed-End Funds 16-18 (July 1992) (unpublished manuscript, on file with the Stanford Law Review). The result is interpreted as evidence that blockholders receive returns unavailable to other shareholders, primarily through the provision of advisory services for high fees. The larger discounts are then said to result either directly from such wealth transfers or from the reluctance of large blockholders receiving such transfers to open up or liquidate a discounted investment company. Id. at 17. Even if correct, this interpretation has little relevance to evaluation of the MSIC form. As the authors note, a selection bias underlies their result: Large blockholders who wish to improve the performance of a discounted closed-end fund will open-end it or liquidate it, thereby dropping out of the sample. Id. at 3-5. By contrast, an MSIC improves performance through ongoing efforts to monitor portfolio company performance. Furthermore, unlike the closed-end investment fund with a large blockholder as investment advisor, an MSIC has only a one-dimensional relation to its portfolio companies; the MSIC form does not present the opportunities for self-dealing reported in connection with advisory fees paid by closed-end investment companies.

Another empirical study reported that companies with a large block of stock held by another corporation earned positive returns over the period studied, but lower returns than a control group without a blockholder. Stuart Rosenstein \& David F. Rush, The Stock Return Performance of Corporations That Are Partially Owned By Other Corporations, 13 J. FIN. RES. 39, 50 (1990). The study's results are difficult to evaluate, because it does not disclose the character of the blockholders. The results support the conjecture that the average reported may reflect a mix of blockholders who do monitor and those who, like the closed-end blockholders, engage in self-dealing. A subsample of companies in which Victor Posner was the blockholder performed substantially worse than the overall sample. Id.

97. See, e.g., Steven Kaplan, The Effects of Management Buyouts on Operating Performance and Value, 24 J. FIN. ECON. 217 (1989); Abbie J. Smith, Corporate Ownership Structure and Performance: The Case of Management Buyouts, 27 J. FiN. ECON, 143 (1990); see also Black, supra note 92, at 924-25 \& nn.129-134 (citing studies on the effects of LBOs on corporate performance).

98. Institutional ownership is associated with higher Tobin's q ratios, and there is some evidence that institutional shareholders are more likely to exercise an informed vote than other shareholders. See Black, supra note 92, at 926-27. 
monitoring capabilities and in its investment incentive to improve corporate performance.

Stepping back from the data, there are good prospects that the expert monitoring of a well-managed MSIC could add significant value to at least some public corporations in the American market. Indeed, a different conclusion is almost inconceivable, given the extended theoretical literature on the agency problem in the Berle-Means corporation, and the equally rich store of anecdotal evidence on the propensity of managers to place their own welfare over that of their shareholders. Less certain is whether American MSICs could generate enough value to overcome the handicap of the market discounts that they would almost certainly bear. But the risk that American MSICs might not succeed on this score is hardly an adequate reason to maintain the proscriptions of the 1940 Act. The rewards of success would be a significant governance reform in the American market with the potential to benefit not only investors in MSICs, but also investors in portfolio companies and in the market more generally. If MSICs failed, the only losers would be the shareholders of the MSICs. The possibility of losses for such investors is no different than for any other promising but risky venture. ${ }^{99}$ The full disclosure required of public companies by the federal securities laws would assure that, if American MSICs were permitted, no one would mistake them for a qualitatively less risky investment such as a diversified passive investment company.

\section{CONCLUSION}

As with other organizational forms, differing regulatory, institutional, and political environments create a diversity of corporate governance structures. Particular structures are neither functional nor dysfunctional in the abstract; everything depends on the national context in which they must operate. Despite such contingency, however, specific governance structures can be evaluated against larger national patterns or frameworks of corporate governance, such as the one-dimensional American pattern of shareholderoriented governance. In particular, distinguishing between broader national patterns of governance and specific governance structures permits a reformist approach to comparative corporate governance. A specific structure that

99. No reason exists to expect every MSIC to succeed over all periods. For example, Corporate Partners, a recently created "white squire" fund, appears to have suffered a substantial loss on its holdings in Phar-Mor, Inc. when it was recently discovered that senior Phar-Mor executives engaged in massive embezzlement and substantially misstated the company's financial condition, despite the presence of a prominent outside auditor. See George Anders, Phar-Mor Scandal Clouds Corporate Partners, WALl ST. J., Aug. 6, 1992, at C1. Even the best monitor (or auditor) will not always detect willful fraud or illegality, as indicated by the presence of two of the most respected investor-monitors-Warren Buffett and Charles Munger, chairman and vice chairman of Berkshire Hathaway - on the board of Salomon, Inc. during its period of illegal conduct and subsequent delay in reporting. Fortunately, serious fraud committed by senior executives remains an anomaly in American business, and Corporate Partners' overall annual returns, excluding the Phar-Mor investment, appear to average approximately 17\%. Moreover, the extent to which "white squire" funds or Berkshire Hathaway actually pursue the active monitoring strategy contemplated for an MSIC is unclear. 
has evolved in its own regulatory and political environment might well suggest an incremental reform in a foreign environment, providing that the governance structure at issue fits the dominant governance pattern of the putative host environment.

In this article, we have argued that the MSIC is one such governance structure that can be introduced as an incremental reform in the American regulatory and political environment. The MSIC follows a European, and more particularly Swedish, model of investment companies that specialize in providing long-term monitoring services to the shareholders of publiclytraded corporations. Consistent with the dominant American pattern of corporate governance, the MSIC acts as a pure shareholder holding large minority stakes in a portfolio of public companies. The MSIC provides monitoring services to its portfolio companies, e.g., through expert directors, and earns an investment return for doing so by increasing the value of its equity holdings. Thus, the MSIC serves as a market response to the agency problem created by the dispersed ownership of equity in the Berle-Means corporation. Market experimentation with the MSIC strategy in America has been limited, largely because the Investment Company Act of 1940 effectively prohibits MSICs. We therefore urge that the MSIC be exempted from the coverage of the 1940 Act, or at least from the Act's most onerous provisions. There is good reason to believe that this Swedish transplant might thrive in the American market if the regulatory barriers were lowered, and there is little to lose, from the perspective of the broader American framework of corporate governance, by experimenting with the MSIC form. 